\title{
KOMPETENSI PERADILAN TATA USAHA NEGARA TERHADAP PENGAWASAN PENYELENGGARAAN PEMERINTAHAN DITINJAU DARI PERLUASAN ASAS-ASAS UMUM PEMERINTAHAN YANG BAIK PASCA BERLAKUNYA UNDANG-UNDANG NOMOR 30 TAHUN 2014 TENTANG ADMINISTRASI PEMERINTAHAN
}

\author{
Devi Melissa Silalahi \\ Pascasarjana Fakultas Hukum Universitas Indonesia \\ Jl. Salemba Raya 4, Kampus Universitas Indonesia, Salemba \\ devimelissasilalahi@gmail.com
}

\begin{abstract}
Abstrak
Tulisan ini mendiskusikan pengawasan terhadap penyelenggaraan pemerintahan yang dilakukan oleh Badan Peradilan, dalam hal ini Peradilan Tata Usaha Negara. Sebab sebagaimana diketahui, Peradilan Tata Usaha Negara dibentuk guna menyelesaikan sengketa bersifat administrasi yang terjadi antara pemerintah dan warga masyarakat. Adapun, tujuan dari tulisan ini adalah mengetahui kompetensi yang dimiliki oleh Peradilan Tata Usaha Negara pasca berlakunya Undang-Undang Nomor 30 Tahun 2014 tentang Administrasi Pemerintahan. Sebab, dalam undang-undang tersebut diatur hukum material. Selain itu, Undang-Undang Nomor 30 Tahun 2014 juga mengatur perluasan jenis Asas-Asas Umum Pemerintahan Yang Baik yang dapat dijadikan dasar gugatan bagi masyarakat sekaligus alat uji bagi Hakim atas suatu Keputusan Tata Usaha Negara. Dalam Pasal 10 Undang-Undang Nomor 30 Tahun 2014 disebutkan terdapat delapan asas. Akan tetapi, diluar kedelapan asas dimaksud Hakim diberikan suatu keleluasaan untuk menerapkan asas-asas umum lainnya sebagai dasar pertimbangan hukum. Melalui Undang-Undang No. 30 Tahun 2014 maka semakin kokohlah upaya peradilan administrasi yang dilakukan oleh Peradilan Tata Usaha Negara. Disisi lain, Undang-Undang No. 30 Tahun 2014 tersebut telah mewajibkan pemerintah untuk memperhatikan Asas-Asas Umum Pemerintahan Yang Baik dalam setiap penerbitan Keputusan Tata Usaha Negara. Sebab, sah atau tidaknya suatu Keputusan Tata Usaha Negara didasarkan pada ketentuan peraturan perundang-undangan dan Asas-Asas Umum Pemerintahan Yang Baik.
\end{abstract}

Kata kunci: Kompetensi, Peradilan Tata Usaha Negara, AUPB

\section{Abstract}

This article discusses Administrative Court's control function in governance toward implementation of government's duties. As we know, Administrative Court has its role to resolve any administrative disputes between government and citizens. The aims of this article is to know deeply the competency of Administrative Court after the enactment of Law Number 30 Year 2014 about Government Administration as the law regulates main material sources of state administrative law. This is due to the addition of general principles of good governance's types to file a tort claim for an unlawful act 
committed by government. Moreover, general principles of good governance become a legal instrument for Judges of State Administration Court to review the legality of any decision of State Administration. In the Article 10 Law Number 30 Year 2014 is stated that there are eight types general principle of good governance. However, Judges has a right to look broader and find another types beyond that eight in order to make legal decision. Therefore, Law Number 30 Year 2014 becomes foundation of the main material law of state administrative procedure law. In the other hand, Law Number 30 Year 2014 requires government to publish every administrative decree based on provisions in law and general principles of good governance.

Keywords: Competency, State Administration Court, Good Governance

\section{Pendahuluan}

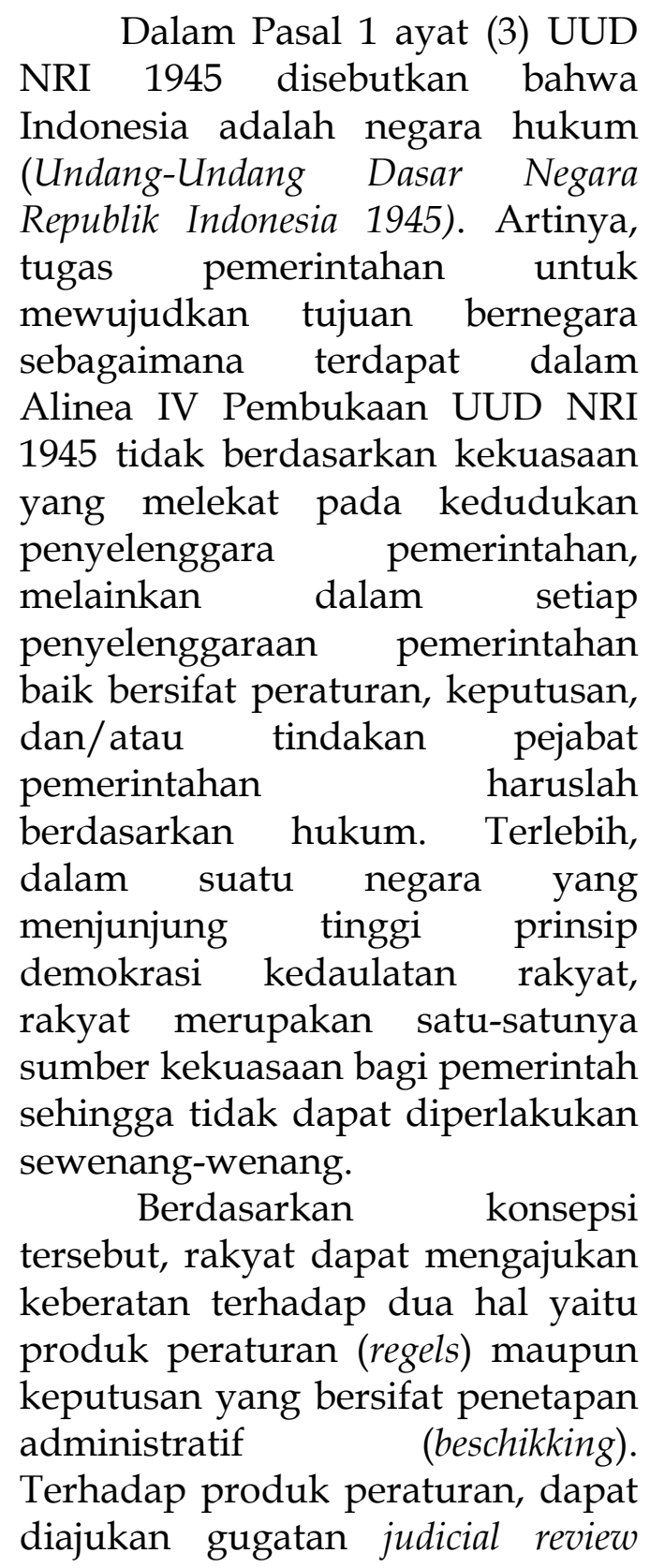

langsung kepada Mahkamah Agung sesuai ketentuan Pasal 24A ayat (1) UUD NRI 1945. Sedangkan, terhadap keputusan yang ditetapkan oleh pejabat pemerintah (KTUN) dapat ditujukan kepada lembaga peradilan lainnya (Asshiddiqie;2013) Adapun, pengajuan keberatan terhadap KTUN dilakukan melalui mekanisme peradilan administrasi negara. Menurut S. Prajudi Atmosudirjo, peradilan administrasi negara adalah setiap bentuk penyelesaian daripada suatu perbuatan (pejabat, instansi) administrasi negara yang dipersoalkan oleh masyarakat, instansi mayarakat (perusahaan, yayasan, perhimpunan, dan sebagainya) atau sesama instansi pemerintah (Atmosudirjo;1994). Atas pengertian tersebut, maka kita ketahui lembaga peradilan yang menangani permasalahan terkait administrasi negara adalah Peradilan Tata Usaha Negara (PTUN).

Sebagaimana diketahui, PTUN dibentuk berdasarkan UU No. 5 Tahun 1986 sebagaimana telah diubah dengan UU No. 9 Tahun 2004 dan UU No. 51 Tahun 
2009. Dalam Konsiderans UU tersebut disebutkan ide pokok pembentukan PTUN yaitu melakukan fungsi kontrol hukum secara utuh terhadap administrasi pemerintahan sebab dalam pelaksanaannya terdapat kemungkinan timbulnya benturan kepentingan, perselisihan, atau sengketa antara Badan atau Pejabat Tata Usaha Negara dengan warga masyarakat yang dapat merugikan atau menghambat jalannya pembangunan nasional. Dengan demikian, sengketa dimaksud dapat dikategorikan sebagai sengketa TUN.

Adapun, sengketa TUN merupakan sengketa hukum publik sehingga putusannya berlaku bagi siapa saja, tidak hanya para pihak yang bersengketa. Hal ini mengingat asas putusan pengadilan yang memiliki kekuatan mengikat "erga ormes" (Hadjon, et.al.,;2008).

Penyelesaian sengketa TUN dapat dilakukan dengan dua cara yaitu upaya administratif dan gugatan. Penyelesaian sengketa TUN dengan upaya administratif hanya berlaku untuk sengketa TUN yang penyelesaiannya tersedia upaya administratif. Artinya, tidak berlaku untuk semua sengketa TUN. Bentuk upaya administratif dapat berupa keberatan, banding administratif, maupun keberatan dan banding administratif. Untuk mengetahui apakah penyelesaian sengketa TUN tersedia upaya administratif maka dapat diperhatikan peraturan perundang-undangan yang menjadi dasar hukum dikeluarkannya KTUN tersebut.
Disisi lain, penyelesaian sengketa TUN melalui gugatan dilakukan bilamana dalam penyelesaiannya tidak tersedia upaya administratif bahwa dalam peraturan perundang-undangan

dikeluarkannya KTUN tidak diatur ketentuan upaya administratif yang dapat dilalui. Akan tetapi, terdapat kemungkinan juga telah dilaluinya upaya administratif namun terdapat pihak yang masih belum dapat menerima keputusan tersebut (Wiyono;2007).

Selanjutnya, alasan-alasan yang dapat digunakan dalam mengajukan gugatan terhadap keputusan dan/atau tindakan pejabat pemerintah diatur dalam UU PTUN. Salah satunya ialah pelanggaran terhadap Asas-Asas Umum Pemerintahan Yang Baik (AUPB).

Atas hal itu, maka pengambilan putusan di PTUN melihat kepada praktik penggunaan AUPB. Adapun, AUPB sendiri memiliki arti penting bagi sejumlah pihak sebagai berikut (Ridwan; 2016):

1. Bagi administrasi negara, bermanfaat sebagai pedoman dalam melakukan penafsiran dan penerapan terhadap ketentuan-ketentuan

perundang-undangan yang bersifat sumir, samar, atau tidak jelas. Selain itu, membatasi dan menghindari kemungkinan administrasi negara melakukan kebijakan yang jauh menyimpang dari ketentuan perundangundangan. Dengan demikian, administrasi negara diharapkan terhindar dari 
perbuatan onrechtmatige daad, detournement de pouvoir, abus de droit, dan ultravires.

2. Bagi warga masyarakat, sebagai pencari keadilan. AUPB dapat dipergunakan sebagai dasar gugatan sebagaimana disebutkan dalam UU PTUN.

3. Bagi Hakim TUN, dapat dipergunakan sebagai alat menguji dan membatalkan keputusan yang dikeluarkan Badan atau Pejabat TUN.

Lebih lanjut, AUPB dalam UU PTUN dalam perkembangannya mengalami perluasan dengan berlakunya UU No. 30 Tahun 2014 tentang Administrasi Pemerintahan (UU AP). Perluasan tersebut berpengaruh terhadap kompetensi PTUN dalam melaksanakan pengawasan terhadap penyelenggaraan pemerintahan. Hal ini mengingat, sebelum adanya UU AP, Hakim TUN mendasarkan pada pendapat para ahli (doktrin) atau yurisprudensi bilamana terdapat perkara yang hukum materilnya tidak diatur dalam UU PTUN (Naskah Akademik Rancangan Undang-Undang Tentang Administrasi Negara).

Berdasarkan hal di atas, tulisan ini akan mengkaji lebih dalam kompetensi PTUN setelah diberlakukannya UU AP. Hal ini guna mengetahui pelaksanaan fungsi kontrol terhadap tindakan pemerintahan dalam meningkatkan kualitas badan/pejabat pemerintahan dalam mewujudkan tujuan bernegara.

\section{Perumusan Masalah}

Berdasarkan latar belakang yang telah diuraikan, dapat dikemukakan sejumlah pokok permasalahan sebagai berikut:

1. Bagaimana pengawasan terhadap pemerintah yang dilakukan oleh Badan Peradilan Administrasi?

2. Bagaimana perubahan kontruksi upaya administrasi peradilan dalam paradigama UU AP?

\section{Metode Penelitian}

Penulisan artikel ini menggunakan metode normatif yuridis yang memfokuskan pada bahan pustaka atau data sekunder yang bersifat umum seperti buku teks maupun peraturan perundangundangan.

\section{Mekanisme Pengawasan Terhadap Pemerintah Oleh Badan Peradilan Administrasi Berdasarkan UU PTUN}

Pada hakikatnya, badan peradilan administrasi adalah salah satu badan yang dibentuk untuk dengan cara tertentu mengawasi tindakan pemerintah dan memiliki kewenangan melakukan koreksi terhadap penyimpangan yang dilakukan organ pemerintah disamping organ pengawasan lain (Lotulung; 1993). Hakikat tersebut sejalan dengan kompetensi utama PTUN sebagai badan peradilan administrasi yang dibentuk guna penyelesaian sengketa yang bersifat administrasi antara pemerintah dan warga masyarakat. Atas hal itu, PTUN berfungsi sebagai penjaga terhadap penyelenggaraan pemerintahan dimana bertindak mengawasi tindakan pemerintah 
dalam melaksanakan tugasnya sekaligus memberikan jaminan perlindungan atas hak-hak masyarakat.

Hal ini merupakan konsekuensi Indonesia sebagai negara hukum (rechtsstaat) dengan tiga karateristik utama, yaitu (Soemantri; 1992):

1. pemerintah dalam melaksanakan tugas dan kewajibannya harus berdasar atas hukum atau peraturan perundang-undangan;

2. adanya jaminan terhadap hak asasi manusia;

3. adanya pembagian kekuasaan negara.

Nilai pengawasan terhadap pemerintah terletak pada respons korektif terhadap kekeliruan yang telah dilakukan, pemulihan terhadap akibat yang ditimbulkan, dan pendisiplinan bagi pejabat yang melakukan tindakan (Fachruddin; 2004). Pengawasan merupakan gagasan dalam sistem demokrasi konstitusional dimana terdapat pembatasan kekuasaan bahwa penyelenggaraan pemerintahan memperhatikan kehendak rakyat dan dilaksanakan sepenuhnya berdasarkan hukum.

Pengaturan mengenai mekanisme pengawasan yang dilakukan oleh PTUN diatur dalam UU No. 5 Tahun 1986 sebagaimana telah diubah dengan UU No. 9 Tahun 2004 dan UU No. 51 Tahun 2009. Meskipun mengalami dua kali perubahan, masing-masing UU tersebut dinyatakan tetap berlaku sepanjang tidak mengalami perubahan dalam pasalnya.

Dalam Pasal 53 ayat (2) UU No. 5 Tahun 1986 ditekankan alasan pengajuan gugatan hanya terhadap tiga hal, yaitu (i) KTUN bertentangan dengan peraturan perundang-undangan, (ii) didasari oleh adanya penyalahgunaan wewenang, dan (iii) tidak mempertimbangkan kepentingan terkait (Undang-Undang Peradilan Tata Usaha Negara). Poin (ii) dan (iii) secara implisit dapat dikategorikan sebagai AUPB. Hal ini mengingat, menurut Philipus M. Hadjon, AUPB harus dipandang sebagai norma hukum yang tidak tertulis namun harus senantiasa ditaati oleh pemerintah (Hadjon). Akan tetapi, dalam perkembangannya, pasal tersebut dinilai tidak mengakomodir kebutuhan masyarakat sehingga dilakukan perubahan terhadapnya melalui UU No. 9 Tahun 2004.

Perubahan Pasal 53 ayat (2) tersebut merupakan perubahan paling prinsipil dari keseluruhan perubahan UU. Hal ini disebabkan, pelanggaran terhadap AUPB disebutkan secara eksplisit dalam bunyi pasal sebagai dasar pengajuan gugatan disamping pelanggaran terhadap peraturan perundang-undangan (UndangUndang Perubahan Atas UndangUndang Nomor 5 Tahun 1986 Peradilan Tata Usaha Negara). Dengan pengaturan secara eksplisit tersebut, AUPB dijadikan alat uji bagi Hakim TUN terhadap KTUN.

Selanjutnya, dalam Penjelasan 53 ayat (2) UU No. 9 Tahun 2004 disebutkan bahwa yang dimaksud dengan AUPB mengacu pada UU No. 28 Tahun 1999 tentang Penyelenggaraan Negara yang Bersih dan Bebas dari Korupsi, 
Kolusi, dan Nepotisme. AUPB dimaksud meliputi enam asas yaitu kepastian hukum, tertib penyelenggaraan negara, keterbukaan, proporsionalitas, profesionalitas, dan akuntabilitas (Undang-Undang Perubahan Atas Undang-Undang Nomor 5 Tahun 1986 Peradilan Tata Usaha Negara).
Uraian atas masing-masing asas dimaksud dapat ditemukan dalam Bagian Penjelasan Pasal 3 UU No. 28 Tahun 1999, sebagai berikut (Undang-Undang Penyelenggaraan Negara yang Bersih dan Bebas dari Korupsi, Kolusi, dan Nepotisme) :

\begin{tabular}{|l|l|l|}
\hline No. & Jenis Asas & Penjelasan \\
\hline 1. & $\begin{array}{l}\text { Kepastian } \\
\text { Hukum } \\
\text { landasan peraturan perundang-undangan, kepatutan, } \\
\text { dan keadilan dalam setiap kebijakan penyelenggara } \\
\text { negara. }\end{array}$ \\
\hline 2. & $\begin{array}{l}\text { Tertib } \\
\text { Penyelenggaraa } \\
\text { n Negara }\end{array}$ & $\begin{array}{l}\text { Asas yang menjadi landasan keteraturan, keserasian, } \\
\text { dan keseimbangan dalam pengendalian } \\
\text { penyelenggaraan negara. }\end{array}$ \\
\hline 3. & Keterbukaan & $\begin{array}{l}\text { Asas yang membuka diri terhadap hak masyarakat } \\
\text { untuk memperoleh informasi yang benar, jujur, dan } \\
\text { tidak diskriminatif tentang penyelenggaraan negara } \\
\text { dengan tetap memperhatikan perlindungan atas hak } \\
\text { asasi pribadi, golongan, dan rahasia negara. }\end{array}$ \\
\hline 4. & Proporsionalitas & $\begin{array}{l}\text { Asas yang mengutamakan keseimbangan antara hak } \\
\text { dan kewajiban penyelenggara negara. }\end{array}$ \\
\hline 5. & Profesionalitas & $\begin{array}{l}\text { Asas yang mengutamakan keahlian yang } \\
\text { berlandaskan kode etik dan ketentuan peraturan } \\
\text { perundang-undangan yang berlaku. }\end{array}$ \\
\hline 6. & Akuntabilitas & $\begin{array}{l}\text { Asas yang menentukan bahwa setiap kegiatan dan } \\
\text { hasil akhir dari kegiatan penyelenggara negara harus } \\
\text { dapat dipertanggungjawabkan kepada rakyat sebagai } \\
\text { pemegang kedaulatan tertinggi negara sesuai dengan } \\
\text { ketentuan peraturan perundang-undangan yang } \\
\text { berlaku. }\end{array}$ \\
\hline
\end{tabular}

Melalui ketentuan baru tersebut, maka pejabat pemerintah diharapkan dalam membuat KTUN tidak hanya berpedoman pada peraturan perundang-undangan melainkan juga kepada AUPB. Sebab, pelanggaran terhadap AUPB secara eksplisit telah diakui bahkan dijadikan alat uji bagi Hakim TUN untuk menyatakan batal atau tidak sahnya suatu KTUN. 
Perubahan Konstruksi Upaya Administrasi Peradilan Dalam Paradigma UU AP

Landasan filosofis dan sosiologis pembentukan UU AP sejalan dengan UU PTUN. Hal ini dapat kita lihat dalam konsideran UU AP yaitu diperlukannya landasan hukum bagi keputusan dan/atau tindakan pejabat pemerintahan untuk mewujudkan pemerintahan yang baik. Disamping hal itu, juga terdapat kebutuhan dalam penyelesaian permasalahan penyelenggaraan pemerintahan sekaligus memberikan perlindungan hukum bagi masyarakat maupun pejabat pemerintahan.
Dalam UU AP, terdapat penambahan jenis AUPB. Dalam Pasal 10 ayat (1) disebutkan bahwa AUPB meliputi delapan asas yaitu kepastian hukum, kemanfaatan, ketidakberpihakan, kecermatan, tidak menyalahgunakan kewenangan, keterbukaan, kepentingan umum, dan pelayanan yang baik (Undang-Undang Administrasi Pemerintahan).

Uraian atas masing-masing asas dimaksud dapat ditemukan dalam Bagian Penjelasan Pasal 10 ayat (1) UU AP, sebagai berikut (Undang-Undang Pemerintahan):

\begin{tabular}{|c|c|c|}
\hline No. & Jenis Asas & Penjelasan \\
\hline 1. & $\begin{array}{l}\text { Kepastian } \\
\text { Hukum }\end{array}$ & $\begin{array}{l}\text { Asas dalam negara hukum yang mengutamakan } \\
\text { landasan ketentuan peraturan perundang- } \\
\text { undangan, kepatutan, keajegan, dan keadilan } \\
\text { dalam setiap kebijakan penyelenggaraan } \\
\text { pemerintahan. }\end{array}$ \\
\hline 2. & Kemanfaatan & $\begin{array}{l}\text { Manfaat yang harus diperhatikan secara seimbang } \\
\text { antara kepentingan individu yang satu dengan } \\
\text { kepentingan individu yang lain, kepentingan } \\
\text { individu dengan masyarakat, kepentingan warga } \\
\text { masyarakat dan masyarakat asing, kepentingan } \\
\text { kelompok masyarakat yang satu dan kepentingan } \\
\text { kelompok masyarakat yang lain, kepentingan } \\
\text { pemerintah dengan warga masyarakat, } \\
\text { kepentingan generasi yang sekarang dan } \\
\text { kepentingan generasi mendatang, kepentingan } \\
\text { manusia dan ekosistemnya, serta kepentingan pria } \\
\text { dan wanita. }\end{array}$ \\
\hline 3. & $\begin{array}{l}\text { Ketidakberpihaka } \\
\text { n }\end{array}$ & $\begin{array}{l}\text { Asas yang mewajibkan badan dan/atau pejabat } \\
\text { pemerintahan dalam menetapkan dan/atau } \\
\text { melakukan keputusan dan/atau tindakan dengan } \\
\text { mempertimbangan kepentingan para pihak secara } \\
\text { keseluruhan dan tidak diskriminatif. }\end{array}$ \\
\hline
\end{tabular}




\begin{tabular}{|c|c|c|}
\hline 4. & Kecermatan & $\begin{array}{l}\text { Suatu keputusan dan/atau tindakan harus } \\
\text { didasarkan pada informasi dan dokumen yang } \\
\text { lengkap untuk mendukung legalitas penetapan } \\
\text { dan/atau pelaksanaan keputusan dan/atau } \\
\text { tindakan sehingga keputusan dan/atau tindakan } \\
\text { yang bersangkutan dipersiapkan dengan cermat } \\
\text { sebelum keputusan dan/atau tindakan tersebut } \\
\text { ditetapkan dan/atau dilakukan. }\end{array}$ \\
\hline 5. & $\begin{array}{l}\text { Tidak } \\
\text { Menyalahgunaka } \\
\text { n Kewenangan }\end{array}$ & $\begin{array}{l}\text { Asas yang mewajibkan setiap badan dan/atau } \\
\text { pejabat pemerintahan tidak menggunakan } \\
\text { kewenangannya untuk kepentingan pribadi atau } \\
\text { kepentingan yang lain dan tidak sesuai dengan } \\
\text { tujuan pemberian kewenangan tersebut, tidak } \\
\text { melampaui, tidak menyalahgunakan, dan/atau } \\
\text { tidak mencampuradukkan kewenangan. }\end{array}$ \\
\hline 6. & Keterbukaan & $\begin{array}{l}\text { Asas yang melayani masyarakat untuk } \\
\text { mendapatkan akses dan memperoleh informasi } \\
\text { yang benar, jujur, dan tidak diskriminatif dalam } \\
\text { penyelenggaraan pemerintahan dengan tetap } \\
\text { memperhatikan perlindungan atas hak asasi } \\
\text { pribadi, golongan, dan rahasia negara. }\end{array}$ \\
\hline 7. & $\begin{array}{l}\text { Kepentingan } \\
\text { Umum }\end{array}$ & $\begin{array}{l}\text { Mendahulukan kesejahteraan dan kemanfaatan } \\
\text { umum dengan cara yang aspiratif, akomodatif, } \\
\text { selektif, dan tidak diskriminati. }\end{array}$ \\
\hline 8. & $\begin{array}{l}\text { Pelayanan } \\
\text { Yang Baik }\end{array}$ & $\begin{array}{l}\text { Memberikan pelayanan yang tepat waktu, } \\
\text { prosedur dan biaya yang jelas, sesuai dengan } \\
\text { standar pelayanan dan ketentuan peraturan } \\
\text { perundang-undangan. }\end{array}$ \\
\hline
\end{tabular}

Namun demikian, dalam Pasal 10 ayat (2) UU AP disebutkan bahwa diluar delapan asas di atas, asasasas umum lainnya dapat diterapkan sepanjang dijadikan dasar penilaian Hakim yang tertuang dalam putusan pengadilan yang berkekuatan hukum tetap. Maksud dari asas-asas umum lainnya di luar AUPB adalah asas yang bersumber dari putusan pengadilan negeri yang tidak dibanding atau putusan pengadilan tinggi yang tidak dikasasi atau putusan Mahkamah Agung (Undang-Undang Administrasi Pemerintahan).

Atas pengaturan tersebut, maka jenis AUPB yang dijadikan dasar dalam pengajuan gugatan terhadap tindakan badan/pejabat 
pemerintahan perluasan. Dengan demikian, penggugat memiliki banyak pilihan asas untuk menggugat kepada PTUN. Di sisi lain, perluasan jenis asas tersebut memiliki implikasi terhadap tindakan badan/pejabat pemerintahan bahwa dalam menerbitkan KTUN wajib memperhatikan asas-asas dimaksud. Hal ini mengingat dalam Pasal 52 ayat (2) UU AP disebutkan bahwa sahnya keputusan didasarkan pada ketentuan peraturan perundang-undangan dan AUPB (Undang-Undang Administrasi Pemerintahan).

Selain itu, dalam Pasal 66 ayat (3) UU AP disebutkan bahwa keputusan pembatalan dapat dilakukan salah satunya oleh putusan pengadilan (UndangUndang Administrasi Pemerintahan). Hal ini berarti, UU AP memberikan suatu legitimasi terhadap Hakim untuk menerapkan AUPB sebagai alat uji terhadap KTUN. Terlebih, AUPB bukan merupakan kewajiban alternatif bagi pejabat pemerintahan dalam melakukan penyelenggaraan administrasi pemerintahan, melainkan kewajiban kumulatif disamping ketentuan peraturan perundang-undangan dan kebijakan pemerintahan sebagaimana diatur dalam Pasal 7 ayat (1) UU AP (Undang-Undang Administrasi Pemerintahan).

Banyaknya pengaturan AUPB dalam UU AP semakin memperkokoh AUPB sebagai norma hukum yang mengikat dalam penyelenggaraan pemerintahan. Hal ini berbanding terbalik dengan pengaturan dalam UU PTUN.

Berdasarkan hal tersebut, maka dapat dilihat bahwa UU AP merupakan babak baru dalam upaya administrai yang dilakukan PTUN dimana memberikan kewenangan lebih luas kepada PTUN untuk melakukan kontrol hukum terhadap administrasi pemerintahan (Soebechi; 2014).

\section{Perbandingan AUPB Dalam UU PTUN dan UU AP}

Melihat penjelasan di atas, maka pengaturan AUPB dalam UU PTUN dan UU AP dapat dibandingkan dalam tabel berikut ini:

\begin{tabular}{|l|l|}
\hline \multicolumn{2}{|l|}{ Perihal: Dasar Pengajuan Gugatan } \\
\hline UU No. 5/1986 & $\begin{array}{l}\text { KTUN bertentangan dengan peraturan perundang- } \\
\text { undangan, didasari oleh adanya penyalahgunaan } \\
\text { wewenang, dan tidak mempertimbangkan } \\
\text { kepentingan terkait (Pasal 53 ayat 2). }\end{array}$ \\
\hline UU No. 9/2004 & $\begin{array}{l}\text { KTUN bertentangan dengan peraturan perundang- } \\
\text { undangan; bertentangan dengan AUPB (Pasal 53 ayat } \\
\text { 2). }\end{array}$ \\
\hline UU No. 51/2009 & $\begin{array}{l}\text { Sama dengan UU No. 9/2004 (tidak mengalami } \\
\text { perubahan). }\end{array}$ \\
\hline UU No. 30/2014 & $\begin{array}{l}\text { Penyelenggaraan pemerintahan yang tidak sesuai } \\
\text { dengan ketentuan peraturan perundang-undangan, } \\
\text { kebijakan pemerintah, dan AUPB (Pasal 7). }\end{array}$ \\
\hline
\end{tabular}




\begin{tabular}{|c|c|}
\hline \multicolumn{2}{|c|}{ Perihal: Jenis dan Keberadaan AUPB } \\
\hline UU No. 5/1986 & $\begin{array}{l}\text { Terdapat dua jenis AUPB yang disebutkan secara } \\
\text { implisit dalam Pasal } 53 \text { ayat (2). }\end{array}$ \\
\hline UU No. 9/2004 & $\begin{array}{l}\text { Terdapat enam jenis AUPB yang disebutkan secara } \\
\text { eksplisit dalam Pasal } 53 \text { ayat (2) dan Bagian } \\
\text { Penjelasan. }\end{array}$ \\
\hline UU No. 51/2009 & $\begin{array}{l}\text { Sama dengan UU No. 9/2004 (tidak mengalami } \\
\text { perubahan). }\end{array}$ \\
\hline UU No. 30/2014 & $\begin{array}{l}\text { Terdapat delapan jenis AUPB yang disebutkan secara } \\
\text { eksplisit dalam Pasal 10. Namun, norma AUPB } \\
\text { tersebut bersifat terbuka. Artinya, disamping delapan } \\
\text { jenis AUPB dimaksud, Hakim dapat menerapkan } \\
\text { asas umum lainnya sebagai dasar penilaian. }\end{array}$ \\
\hline \multicolumn{2}{|c|}{ Perihal: Fungsi AUPB Bagi Hakim } \\
\hline UU No. 5/1986 & \multirow{4}{*}{$\begin{array}{l}\text { Alat bukti bagi Hakim menguji keabsahan suatu } \\
\text { KTUN. }\end{array}$} \\
\hline UU No. 9/2004 & \\
\hline UU No. 51/2009 & \\
\hline UU No. 30/2014 & \\
\hline \multicolumn{2}{|c|}{ Perihal: Fungsi AUPB Bagi Penggugat } \\
\hline UU No. 5/1986 & Dasar pengajuan gugatan. \\
\hline UU No. 9/2004 & $\begin{array}{l}\text { Dasar pengajuan gugatan, namun hanya sebagai } \\
\text { alasan tambahan karena bersifat alternatif. Artinya, } \\
\text { jika penggugat menggunakan alasan pertama yaitu } \\
\text { pelanggaran terhadap ketentuan peraturan } \\
\text { perundang-undangan saja, maka alasan terhadap } \\
\text { pelanggaran AUPB tidak perlu dimuat lagi. }\end{array}$ \\
\hline UU No. 51/2009 & $\begin{array}{l}\text { Sama dengan UU No. 9/2004 (tidak mengalami } \\
\text { perubahan). }\end{array}$ \\
\hline UU No. 30/2014 & $\begin{array}{l}\text { Dasar pengajuan gugatan, dimana bersifat kumulatif } \\
\text { terhadap kepatuhan atas peraturan perundangan- } \\
\text { perundangan maupun kebijakan pemerintahan. }\end{array}$ \\
\hline \multicolumn{2}{|c|}{ Perihal: Jumlah Pasal Terkait AUPB } \\
\hline UU No. 5/1986 & 1 Pasal. \\
\hline UU No. 9/2004 & 1 Pasal. \\
\hline UU No. 51/2009 & $\begin{array}{l}\text { Sama dengan UU No. 9/2004 (tidak mengalami } \\
\text { perubahan). }\end{array}$ \\
\hline UU No. 30/2014 & 16 Pasal. \\
\hline
\end{tabular}

Dari tabel perbandingan tersebut, dapat kita ketahui bahwa dalam seluruh UU PTUN, pengaturan
AUPB tidak secara tegas dirinci sehingga memiliki kedudukan yang lemah. Terlebih, hanya terdapat 
satu pasal yang mengaturnya. Namun, hal ini berbanding terbalik dengan UU AP dimana banyaknya pasal membuat kedudukan AUPB sangatlah kuat sebagai norma yang mengikat. Bahkan, norma AUPB dalam UU AP bersifat terbuka dimana Hakim diberikan keleluasaan dalam melakukan penilaian terhadap perkara berdasarkan asas umum lainnya diluar AUPB. Kedudukan AUPB dalam UU AP mengukuhkan kewajiban pemerintah untuk menjadikannya sebagai pedoman dalam pembuatan setiap KTUN. Sebab, bilamana KTUN tidak dibuat berdasarkan ketentuan peraturan perundang-undangan dan AUPB maka dapat dibatalkan oleh PTUN.

\section{Contoh Kasus}

Terdapat sejumlah Putusan yang dapat di analisis dalam penerapannya terhadap AUPB, diantaranya:

\section{i. Putusan Mahkamah Agung No. 489 K/TUN/2001 \\ Dalam perkara ini Pemohon} adalah Suhaili Saun (Direktur PT. Volex Batam Indah) dan Termohon adalah Badan Koordinasi Penanaman Modal. Perkara bermula dari PT. Volex Indonesia yang tiba-tiba menempati tanah dan menggunakan fasilitas milik PT. Volex Batam Indah. Atas hal itu, Pemohon menyampaikan surat kepada Termohon yang pada intinya memohon pencabutan izin PT. Volex Indonesia. Namun, Termohon tidak menanggapi permohonan tersebut. Pemohon pun kemudian mendaftarkan gugatannya kepada PTUN Jakarta dengan objek sengketa keputusan fiktif negatif dari Tergugat. Pada pengadilan tingkat pertama, Pemohon menang. Sedangkan, pada pengadilan tingkat banding Pemohon kalah. Namun, pada akhirnya, Pemohon kembali dimenangkan pada tingkat kasasi. Adapun, salah satu pertimbangan hukum yang digunakan oleh Mahkamah Agung adalah pemberian izin oleh Badan/Pejabat Tata Usaha Negara terhadap suatu perusahaan lain yang masih memiliki izin, dalam hal ini izinnya belum dicabut, merupakan pelanggaran atas AUPB sebagaimana terdapat dalam UU PTUN yaitu Asas Kepastian Hukum. Seharusnya, tumpang tindih (overlapping) tidak terjadi bilamana Termohon bertindak memperhatikan AUPB yaitu mengeluarkan izin PT. Volex Indonesia dengan terlebih dahulu membatalkan izin PT. Volex Batam Indah yang masih berlaku. Atas hal itu, Pejabat TUN wajib memahami dan menjalankan aturan perundang-undangan pada saat menerbitkan suatu keputusan dengan memperhatikan aturan sebelumnya yang telah dibuat, apakah aturan baru tersebut akan mengganti aturan yang lama (jika demikian aturan yang lama harus dicabut) atau aturan baru tersebut sifatnya adalah untuk melengkapi aturan yang sudah ada sebelumnya.

\section{ii. Putusan PTUN No. 26/G/2017/PTUN.ABN}

Dalam perkara ini Pemohon adalah Aminah Bin Hatim dan Tergugat adalah Kepala Kantor Pertanahan Kabupaten Maluku Tenggara. Perkara bermula dari 
pengajuan surat permohonan Penggugat kepada Tergugat perihal pendaftaran peralihan hak atas Sertifikat Hak Milik No. 219/Ohoijang-Langgur yang semula atas nama ayah Penggugat kepada Penggugat. Namun, Tergugat menanggapi bahwa Penggugat tidak dapat melanjutkan permohonan peralihan hak karena diatas tanah tersebut terdapat Sertifikat Hak Milik No. 365/Ohoijang-Watdek an. Fenanlampir. Atas hal itu, Penggugat mendaftarkan gugatannya kepada PTUN. Dalam pertimbangan hukumnya, Majelis hakim mendapati pokok permasalahan terkait dengan prosedur dan substansi dari penerbitan objek sengketa yaitu telah terbit dua sertifikat hak milik di atas satu lokasi tanah yang sama sehingga terjadi tumpang tindih diantara kedua sertifikat hak milik tersebut. Selain itu, Majelis Hakim berpendapat bahwa Tergugat terbukti dalam proses penerbitan Sertifikat Hak Milik No. 365 tidak melakukan penyelidikan riwayat bidang tanah dengan benar dan cermat karena melakukan pengukuran di atas tanah yang telah memiliki Sertifikat Hak Milik No. 218 milik Penggugat sehingga mengakibatkan ada dua Sertifikat Hak Milik di atas lokasi tanah yang sama. Dengan demikian, Majelis Hakim berkesimpulan bahwa Sertifikat Hak Milik NO. 365 yang diterbitkan oleh Tergugat telah melanggar peraturan perundangundangan yang berlaku dan AUPB yaitu Asas Kecermatan dan Asas Kepastian Hukum. Hal ini disebabkan, Tergugat dalam menerbitkan objek sengketa a quo tidak cermat dalam meneliti data fisik maupun data yuridis secara menyeluruh serta mengabaikan kepentingan Penggugat sehingga menimbulkan ketidakpastian hukum karena adanya dualisme kepemilikan hak dimana objek sengketa telah cacat yuridis baik dari aspek prosedur maupun substansinya sebagaimana dimaksud dalam Pasaal 52 UU AP. Dengan demikian, gugatan Penggugat dikabulkan seluruhnya.

\section{Simpulan}

$\begin{array}{ccc}\text { Dari } & \text { hasil } & \text { kajian, } \\ \text { dididapatkan } & \text { simpulan } & \text { bahwa }\end{array}$ Perubahan Pasal 53 ayat (2) merupakan perubahan prinsipil dalam UU PTUN karena AUPB secara eksplisit diakui bahkan dijadikan alat uji bagi Hakim TUN terhadap suatu KTUN. Namun demikian, sejak berlakunya UU AP terdapat perluasan jenis AUPB yang dijadikan dasar gugatan dimana dalam Pasal 10 ayat (1) disebutkan adanya delapan asas. Bahkan, diluar kedelapan asas tersebut Hakim diberikan keleluasaan untuk menerapkan asas-asas umum lainnya sebagai dasar pertimbangan. Dengan adanya UU AP yang mengatur hukum materil maka semakin kokohlah upaya peradilan administrasi yang dilakukan oleh PTUN. Hal ini mengingat, sebelumnya UU PTUN hanya mengatur hukum formil. Di sisi lain, sebagai landasan hukum atas penyelenggaraan pemerintahan, badan/pejabat pemerintah wajib memperhatikan AUPB dalam penerbitan setiap KTUN. Sebab, dalam Pasal 52 ayat 
(2) disebutkan bahwa sah atau tidaknya keputusan didasarkan pada ketentuan peraturan perundangan-undangan dan AUPB. Dengan demikian, jika suatu KTUN tidak dibuat berdasarkan ketentuan Pasal 52 ayat (2) tersebut maka KTUN dapat dibatalkan.

\section{Saran}

$\begin{array}{rrr}\text { Disarankan } & \text { agar } & \text { dalam } \\ \text { kondisi apapun } & \text { AUPB } & \text { tetap }\end{array}$ dipertahankan dalam peraturan perundang-undangan sebagai salah satu dasar pengajuan gugatan terhadap tindakan badan/pejabat pemerintahan. Hal ini mempertimbangkan sejumlah manfaat yang diperoleh, yaitu:

i. Pedoman bagi badan/pejabat pemerintah mengedepankan prinsip kehati-hatian dalam penerbitan KTUN sesuai asas-asas yang diwajibkan;

ii. Alat uji bagi Hakim atas keabsahan suatu KTUN yang dapat mengarahkan pada adanya pembatalan. Terlebih, putusan TUN nantinya bersifat mengikat dan memiliki kekuatan hukum tetap;

iii. UU AP telah memberikan ruang kepada Hakim untuk kembali bersifat aktif yaitu melakukan pengembanganpengembangan guna menghasilkan putusan TUN yang lebih berkualitas. Pengembangan dilakukan dengan perluasan pemikiran dan interpretasi terhadap asas-asas umum lainnya diluar yang diatur dalam undang-undang.
Terkait poin iii di atas, maka diharapkan agar dalam setiap program pendidikan dan pelatihan Calon Hakim dimasukkan kurikulum terkait AUPB. Kurikulum tersebut sangatlah penting agar Calon Hakim memiliki kompetensi untuk mengembangkan pemikiran dalam relevensinya terhadap penyelesaian sengketa TUN yang dewasa ini sangat varian.

\section{Daftar Pustaka}

\section{Buku}

Asshiddiqie, Jimly. Pengantar Ilmu Hukum Administrasi Negara. Jakarta: Rajawali Pers, 2013.

Atmosudirjo, S. Prajudi. Hukum Administrasi Negara. Jakarta: Ghalia Indonesia, 1994.

Fachruddin, Irfan. Pengawasan Peradilan Administrasi Terhadap Tindakan Pemerintah. Bandung: Alumni, 2004.

Hadjon, M. Philipus. et.al. Pengantar Hukum Administrasi Indonesia. Yogyakarta: Gadjah Mada University Press, 2008.

HR, Ridwan. Hukum Administrasi Negara. Jakarta: Rajawali Pers, 2016.

Kementerian Pendayagunaan Aparatur Negara dan Reformasi Birokrasi. Naskah Akademik Rancangan Undang-Undang Administrasi Negara. Jakarta: Kementerian

Pendayagunaan Aparatur Negara dan Reformasi Birokrasi, 2004. 
Lotulung, Paulus Effendie. Beberapa Sistem Tentang Kontrol Segi Hukum Terhadap Pemerintah. Bandung: Citra Aditya Bakti, 1993.

Soebechi, Imam. Peraturan dan Kontrol Hukum Secara Utuh ditulis dalam Bunga Rampat Peradilan Administrasi Kontemporer. Yogyakarta: Genta Press, 2014.

Soemantri, Sri. Bunga Rampai Hukum Tata Negara Indonesia. Bandung: Alumni, 1992.

Wiyono, R. Hukum Acara Peradilan Tata Usaha Negara. Jakarta: Sinar Grafika, 2007.

\section{Peraturan Perundang-undangan}

Republik Indonesia. Undang-Undang Dasar Negara Republik Indonesia Tahun 1945.

Undang Peradilan Tata
Usaha Negara. UU Nomor
5 Tahun 1986, LN Nomor
77 Tahun 1986, TLN
Nomor 3344.

UndangUndang Penyelenggaraan Negara yang Bersih dan Bebas dari Korupsi, Kolusi, PTUN No. 26/G/2017/PTUN.ABN. dan Nepotisme. UU Nomor 28 Tahun 1999, TLN Nomor 3851.

Undang Perubahan Atas Undang-Undang Nomor 5 Tahun 1986 Peradilan Tata Usaha Negara. UU Nomor 9 Tahun 2004, LN Nomor 35 Tahun 2004, TLN Nomor 4380.

\begin{tabular}{|c|}
\hline $\begin{array}{lr}\text { Undang Perubahan Kedua } \\
\text { Atas } & \text { Undang-Undang }\end{array}$ \\
\hline Nomor 5 Tahun 1986 \\
\hline Peradilan Tata Usaha \\
\hline Negara. UU Nomor 51 \\
\hline Tahun 2009, LN Nomor \\
\hline 160 Tahun 2009, TLN \\
\hline Nomor 5079. \\
\hline Undang Administrasi \\
\hline Pemerintahan. UU Nomor \\
\hline 30 Tahun 2014, LN \\
\hline $\begin{array}{l}\text { Nomor } 292 \text { Tahun 2014, } \\
\text { TLN Nomor } 5601\end{array}$ \\
\hline
\end{tabular}

Lain-Lain

Mahkamah Agung. Indonesia. Putusan MA Nomor 489 K/TUN/2001.

Peradilan Tata Usaha Negara. Putusan 